\title{
下肢骨・軟部悪性腫瘍の術後機能と 心理的問題点
}

丸野紀子*1 三上 真弘*1 檜垣昇三*2 立石昭夫*2

Key words : 下肢骨 - 軟部悪性腫瘍 (malignant musculoskeletal tumor of lower limb), 機能予後 (functional outcome), 患肢温存術 (limb-salvage surgery), 切断 (amputation), 心理的評価 (psychological assessment)

要旨

下肢骨・軟部悪性腫瘍の術後機能と心理的問題点

$$
\begin{aligned}
& \text { 丸野紀子 三上真弘 } \\
& \text { 檜垣昇三 立石昭夫 }
\end{aligned}
$$

50 例の下肢骨・軟部悪性腫悙患者の術後機能と心理面への影響について調查し た. 術後患肢機能評価には, Musculoskeletal Tumor Society の作成した改訂版術 後患肢機能評価(1993) を用い，心理面の評価には，Arthritis Impact Measurement Scale を用いた，症例を切断群と患肢温存群に分け，患肢温存群はさらに原疾患に より，骨腫惶群と軟部腫瘍群に分けて 3 群間で検討した結果，手術に対する満足度 と心理面とに差は認められなかった。骨腫瘍群で，機能予後不良でも，手術に対す る満足度は低下しなかったことから患肢温存術の受け入れは良好と考えられたが, 心理面では不安や抑うつの程度が強かった。

リ八医学 $33: 393-399,1996$

\section{はじめに}

近年，四肢の原発性骨・軟部悪性腫瘍の治療は，集 学的治療により生命予後の向上が得られてきた らに切除縁評価の概念の確立と再建手技の進歩により 患肢温存が可能になり，今日では積極的に患肢温存術 が採用されるようになった。しかし，患肢温存例の術 後機能が切断例より良好であるのかどうか, 手術に対 する満足度は良好であるのか，また心理面でも切断例 よりも有利なのか否かは明白にされていない.

そこで，今回はこれらを明らかにする目的で本研究 を行った.

\section{対 象}

下肢の原発性骨・軟部悪性腫湯例のうち, 術後 1 年 以上経過し, 1994 年 $1 \sim 12$ 月の 1 年間に外来受診した 50 症例について調查した.

性別は, 男性 31 例, 女性 19 例, 手術時年齢の平均 は 36.6 歳（11 80 歳), 調査時年齢の平均は 41.2 歳 (13〜81 歳) で, 術後経過観察期間の平均は 4.6 年 ( 1 〜 16 年) であった。

症例の内訳は, 原発性骨悪性腫瘍 33 例, 原発性軟部 悪性腫崵 17 例で，骨悪性腫瘍は，骨肉腫 17 例，軟骨 肉腫 7 例，悪性線維性組織球腫 $(\mathrm{MFH}) 5$ 例，骨悪性 リンパ腫 3 例, その他 1 例であった. 軟部悪性腫瘍は, 脂肪肉腫 7 例, 滑膜肉腫 2 例, 横紋筋肉腫 2 例, 平滑

1995 年 10 月 3 日受付, 1996 年 3 月 8 日受理

${ }^{* 1}$ 帝京大学医学部リハビリテーション科/ 173 東京都板橋区加賀 2-11-1

*2 同 整形外科/ 同上 
表 1 Musculoskeletal Tumor Society による改訂版術後患肢機能評価（MSTS）

\begin{tabular}{|c|c|c|c|c|c|c|c|}
\hline \multicolumn{4}{|c|}{ Criteria for Either Extremity } & & \multirow{2}{*}{$\begin{array}{c}\text { No. } \\
5\end{array}$} & \multirow{3}{*}{$\begin{array}{r}\text { Description } \\
\text { No limitations }\end{array}$} & \multirow{3}{*}{$\begin{array}{c}\text { Data } \\
\text { Normal dexterity } \\
\text { and sensitivity }\end{array}$} \\
\hline & No. & Description & Data & \multirow{7}{*}{$\begin{array}{l}\text { Manual } \\
\text { Dexterity }\end{array}$} & & & \\
\hline \multirow{9}{*}{ Pain } & 5 & No pain & No medication & & 4 & & \\
\hline & $\begin{array}{l}4 \\
3\end{array}$ & Intermediate & & & $\begin{array}{l}4 \\
3\end{array}$ & Loss of fine & Cannot button, etc or \\
\hline & 3 & $\begin{array}{l}\text { Misabling } \\
\text { Intermediate }\end{array}$ & $\begin{array}{l}\text { Non-Narcotic } \\
\text { analgesics }\end{array}$ & & & movements & $\begin{array}{l}\text { minor loss of sen- } \\
\text { sitivity (specify) }\end{array}$ \\
\hline & $\begin{array}{l}2 \\
1\end{array}$ & \multirow{2}{*}{$\begin{array}{l}\text { Moderate/ } \\
\text { Intermittently } \\
\text { disabling }\end{array}$} & \multirow{2}{*}{$\begin{array}{l}\text { Intermittent } \\
\text { narcotics }\end{array}$} & & 2 & Intermediate & \\
\hline & \multirow{4}{*}{0} & & & & I & Cannot pinch & $\begin{array}{l}\text { Major sensory loss } \\
\text { (specify) }\end{array}$ \\
\hline & & Severe/ & Continuous & & 0 & Cannot grasp & Anesthetic hand \\
\hline & & Continuously & narcotics & & No. & Description & Data \\
\hline & & disabling & & \multirow{8}{*}{$\begin{array}{l}\text { Lifting } \\
\text { Ability }\end{array}$} & 5 & Normal load & Matches normal \\
\hline & No. & Description & Data & & 4 & Intermediate & Less than less \\
\hline \multirow{10}{*}{ Function } & 5 & No restriction & No disability & & & & normal \\
\hline & 4 & Intermediate & & & 3 & Limited & Minor load \\
\hline & 3 & Recreational & Minor & & 2 & Intermediate & Gravity only \\
\hline & & Restriction & disability & & I & Helping only & Cannot overcome \\
\hline & 2 & Intermediate & \multirow{3}{*}{$\begin{array}{l}\text { Major } \\
\text { disability }\end{array}$} & & & & gravity \\
\hline & \multirow[t]{2}{*}{1} & $\begin{array}{l}\text { Partial } \\
\text { Occupational }\end{array}$ & & & 0 & Cannot help & Cannot move \\
\hline & & Restriction & & \multicolumn{4}{|c|}{ Criteria Specific to the Lower Extremity } \\
\hline & \multirow[t]{2}{*}{0} & Total & \multirow{2}{*}{$\begin{array}{l}\text { Complete } \\
\text { disability }\end{array}$} & & No. & Description & Data \\
\hline & & Restriction & & \multirow{8}{*}{ Supports } & 5 & None & No supports \\
\hline & No. & Description & Data & & 4 & Intermediate & $\begin{array}{l}\text { Occasional use of } \\
\text { brace }\end{array}$ \\
\hline \multirow{6}{*}{$\begin{array}{l}\text { Emotional } \\
\text { Acceptance }\end{array}$} & 5 & Enthused & Would recommend & & 3 & Brace & Mostly brace \\
\hline & 4 & Intermediate & to others & & 2 & Intermediate & $\begin{array}{l}\text { Occasional cane/ } \\
\text { crutch }\end{array}$ \\
\hline & 3 & Satisfied & Would do again & & । & One cane of crutch & Mostly cane/ \\
\hline & 2 & Intermediate & & & & & crutch \\
\hline & \multirow[b]{2}{*}{0} & Accepts & $\begin{array}{l}\text { Would repeat } \\
\text { reluctantly }\end{array}$ & & 0 & $\begin{array}{l}\text { Two canes or } \\
\text { crutches }\end{array}$ & $\begin{array}{l}\text { Always canes/ } \\
\text { crutches }\end{array}$ \\
\hline & & Dislikes & Would not repeat & & No. & Description & Data \\
\hline \multicolumn{4}{|c|}{ Criteria Specific to the Upper Extremity } & \multirow{6}{*}{$\begin{array}{r}\text { Walking } \\
\text { Ability }\end{array}$} & $\begin{array}{l}5 \\
4\end{array}$ & $\begin{array}{l}\text { Unlimited } \\
\text { Intermediate }\end{array}$ & Same as preoperative \\
\hline & No. & Description & Data & & 3 & Limited & Significantly less \\
\hline \multirow{10}{*}{$\begin{array}{l}\text { Hand } \\
\text { Positioning }\end{array}$} & \multirow{10}{*}{$\begin{array}{l}5 \\
4 \\
3 \\
2 \\
1 \\
0\end{array}$} & \multirow{10}{*}{$\begin{array}{l}\text { Unlimited } \\
\text { Intermediate } \\
\text { Not above shoulder } \\
\text { or no/Prosupination } \\
\text { Intermediate } \\
\text { Not above waist } \\
\text { None }\end{array}$} & $180^{\circ}$ elevation & & 2 & Intermediate & \\
\hline & & & & & 1 & Inside only & Cannot walk \\
\hline & & & $90^{\circ}$ elevation & & 0 & Not independently & $\begin{array}{l}\text { outside } \\
\text { Can walk only with }\end{array}$ \\
\hline & & & & & & & $\begin{array}{l}\text { assistance or } \\
\text { wheelchair bound }\end{array}$ \\
\hline & & & $\begin{array}{r}30^{\circ} \text { elevation } \\
0^{\circ} \text { elevation }\end{array}$ & & No. & Description & Data \\
\hline & & & & & $\begin{array}{l}5 \\
4\end{array}$ & $\begin{array}{l}\text { Normal } \\
\text { Intermediate }\end{array}$ & No alteration \\
\hline & & & & Gait & 3 & Minor cosmetic & $\begin{array}{l}\text { Cosmetic alteration } \\
\text { only }\end{array}$ \\
\hline & & & & & 2 & Intermediate & \\
\hline & & & & & । & Major cosmetic & $\begin{array}{l}\text { Minor functional } \\
\text { deficit }\end{array}$ \\
\hline & & & & & 0 & Major handicap & $\begin{array}{l}\text { Major functional } \\
\text { deficit }\end{array}$ \\
\hline
\end{tabular}


表 2 各群の手術時年齢, 調查時年齢および経過観察期間

\begin{tabular}{lcccc}
\hline & $\begin{array}{c}\text { 軟部腫瘍群 } \\
(\mathrm{n}=12)\end{array}$ & $\begin{array}{c}\text { 骨腫瘍群 } \\
(\mathrm{n}=29)\end{array}$ & $\begin{array}{c}\text { 切断群 } \\
(\mathrm{n}=9)\end{array}$ & $\mathrm{p}$ 值 \\
\hline 手術時年齢（歳） & $34.1 \pm 14.0$ & $36.5 \pm 19.0$ & $40.3 \pm 24.9$ & NS \\
調査時年歯令（歳） & $36.6 \pm 14.5$ & $41.1 \pm 19.3$ & $47.5 \pm 24.1$ & $N S$ \\
経過観察期間 (年) & $2.5 \pm 1.8$ & $4.5 \pm 3.5$ & $7.2 \pm 1.2$ & $\S$ \\
\hline
\end{tabular}

NS : not significant, §: 軟部腫瘍群と切断群との間に $p<0.05$ で有

意差があったが，骨腫瘍群と切断群との間には有意差はなかった.

筋肉腫 2 例, その他 4 例であった.

発生部位は骨腫瘍では, 膝関節周囲 17 例, 股関節周 囲 12 例，大腿骨骨幹部 4 例であった。軟部腫瘍では， 大腿部 6 例，膝周囲 4 例，股関節周囲 2 例， 下腿部 1 例, 足部 4 例であった。

術式は, 患肢温存術 41 例, 切断術 9 例で, 患肢温存 術は骨腫瘍 29 例, 軟部腫瘍 12 例に行われ, その内容 は, 広範切除術 32 例, 切除術 4 例, 準切除術 5 例であっ た. 骨欠損が生じた 29 例中 16 例は内補填材（欠損部 補填型人工関節 6 例, 人工骨頭 8 例, 人工骨顆 2 例), 4 例はハックステップ釘あるいはプレートと骨移植, 2 例は関節固定術, 6 例は移植骨, 骨セメント, 八イ ドロキシアパタイトなどを用いて再建が行われたが， 骨盤の 1 例は再建術が行われず hanging hip の状態で 経過観察されていた。

切断術は骨腫瘍 4 例, 軟部腫瘍 5 例に行われ, その 内容は片側骨盤切断 2 例, 大腿切断 4 例, 下腿切断 2 例，ボイド切断 1 例であった。

\section{方 法}

術後患肢機能評価は, Musculoskeletal Tumor Society が作成した改訂版術後患肢機能評価 ${ }^{3)}$ (以下, MSTS）を用いて行った（表 1)。これは上下肢共通の 3 項目と, 上下肢別の 3 項目の, 計 6 項目から構成さ れている. 各項目は，一定の基準のもとで $5 \sim 0$ 点の 6 段階で評価を行い，合計点を算出する，下肢の評価 項目は, 〈pain〉〈function〉〈emotional acceptance〉 〈supports〉〈walking ability〉〈gait〉で, 前半の 3 項 目は患者全体の評価であり, 後半の 3 項目は客観的下 肢機能の評価となっている，術前と変化ないものは 5 点で最も良好であり, 最も成績不良のものは 0 点なの
で, 得点が高いほど成績が良好であることを示す，患 肢温存例では，下肢装具の装着が必要な場合は，〈supports〉の項目の得点は 3 点になり, 切断者では, 義足 を装着した場合は, 最高で 3 点となる.また, 〈walking ability〉〈gait〉の項目は, 義足を装着しての能力, す なわち disability のレベルで評価する。

心理面の調查は, Arthritis Impact Measurement Scale (以下, AIMS) ${ }^{4}$ 中の, 不安や抑うつを判定する 12 項目中の 11 項目を用いて評価した. 除外した 1 項 目は,「あなたが死んだほうが周囲の人々に迷惑がかか らないと感じますか？」という質問であったので，今 回の調査対象はすべて悪性腫瘍のために手術を受けて おり, 不適切と判断した. AIMSでは, 調査日以前の 1 カ月間を想起してもらい，質問項目に該当した場合 を 2 点, どちらともいえない場合を 1 点, 該当しない 場合を 0 点として採点し, 合計点を計算する.したがっ て, AIMS では得点が高いほど不安, 抑うつが強く, 心理面に問題があることを示す. AIMS は本来, リウ マチ患者の健康状態を評価するために作成された評価 表であるが, 他の慢性的な骨関節疾患の評価にも臨床 応用されている5 .

全症例を術式により, 切断群（9例）と患肢温存群 (41 例)に分け, さらに患肢温存群は原疾患により, 骨 腫瘍群 (29 例) と軟部腫瘍群（12 例）に分類し, 切断 群, 骨腫瘍群, 軟部腫瘍群の 3 群間で Kruskal-Wallis 検定を用いて比較検討を行った。なお, 軟部腫崵群に は切除縁が骨に及んだ症例はなかった。

各群の手術時年齢, 調査時年齢, 経過観察期間の平 均を表 2 に示した。分散分析およびScheffe の方法で 検定を行ったところ, 経過観察期間で軟部腫瘍群と切 断群の間に $\mathrm{p}<0.05$ の有意差があったが，その他の間 には有意差は認められなかった。 
表 3 補装具の使用状況

\begin{tabular}{lccc}
\hline & $\begin{array}{c}\text { 軟部腫瘍群 } \\
(\mathrm{n}=12)\end{array}$ & $\begin{array}{c}\text { 骨腫瘍群 } \\
(\mathrm{n}=29)\end{array}$ & $\begin{array}{c}\text { 切断群 } \\
(\mathrm{n}=9)\end{array}$ \\
\hline 装具使用状況 & & & \\
あり(時々/常用) & 0 & $11(0 / 11)$ & - \\
なし & 12 & 18 & - \\
\hline 義足使用状況 & & & \\
あり(時々/常用) & - & - & $8(2 / 6)$ \\
なし & - & - & 1 \\
\hline 杖使用状況 & & & \\
あり(時々/常用) & 0 & $14(2 / 12)$ & $4(1 / 3)$ \\
なし & 12 & 15 & 5 \\
\hline 車椅子使用状況 & & & \\
あり & 0 & 0 & 2 \\
なし & 12 & 29 & 7 \\
\hline
\end{tabular}

表 4 各群の MSTS と AIMS の得点の平均值

\begin{tabular}{lcccc}
\hline & $\begin{array}{c}\text { 軟部腫瘍群 } \\
(n=12)\end{array}$ & $\begin{array}{c}\text { 骨腫瘍群 } \\
(\mathrm{n}=29)\end{array}$ & $\begin{array}{c}\text { 切断群 } \\
(\mathrm{n}=9)\end{array}$ & $\mathrm{p}$ 值 \\
\hline MSTS & 4.8 & 4.5 & 4.7 & $\mathrm{NS}$ \\
$\quad$ pain & 4.7 & 3.2 & 3.2 & $*$ \\
$\quad$ function & 4.5 & 4.3 & 3.8 & $\mathrm{NS}$ \\
emotional acceptance & 5 & 3 & 2.1 & $*$ \\
supports & 4.8 & 3.9 & 3.7 & $*$ \\
walking ability & 4.5 & 2.9 & 2.6 & $*$ \\
gait & 28.2 & 21.7 & 20 & $*$ \\
total score & 1.8 & 3.7 & 2.8 & $\mathrm{NS}$ \\
AlMS & & & & \\
\hline
\end{tabular}

NS : not significant, * : 軟部腫瘍群と他の 2 群の間に $\mathrm{p}<0.05$ の有意差あ り。骨腫瘍群と切断群との間には，いずれの項目にも有意差は認められな かった。

\section{結 果}

補装具の使用状況は表 3 に示すごとくで, 軟部腫瘍 群では補装具の使用者はいなかった。骨腫瘍群では, 装具の使用者は 11 例 $(38 \%)$ であり全例が常時装着し ていた，杖の使用者は 14 例 $(48 \%)$ で，うち 4 例は両 松葉杖を必要としていた。

切断群のうち, 片側骨盤切断の 1 例は義足を装着せ ず両松葉杖で移動していたが，残りの 8 例は義足を装 着していた。 また，大腿切断例のうち 2 例は高齢者で あり (調査時 77 歳と 84 歳), 車椅子主体の家庭内生活 を送っていたが，残りの 6 例は義足歩行が自立してい た.
3 群間の MSTS 6 項目および合計得点の平均值, AIMS の得点の平均値の検定結果を表 4 に示した.

MSTS の項目のうち, 〈pain〉〈emotional acceptance $>$ 項目の得点の平均值は 3 群間で統計学的な有 意差が認められなかった。また，AIMSでも同様に統 計学的な有意差は認められなかった。一方, MSTSの 項目のうち〈function〉〈supports〉〈walking ability〉 〈gait〉および合計得点は，軟部腫瘍群と骨腫瘍群との 間，および軟部腫瘍群と切断群の間で有意差が認めら れた. 骨腫瘍群と切断群の間では, MSTSの各項目お よび AIMS のいずれにも有意差は認められなかった。 さらに，3群について MSTS の各項目の得点と AIMS の得点の相関を Spearman の順位相関を用い て検定したところ，骨腫瘍群の〈supports〉および合計 


\section{表 5 各群の MSTS の各項目の得点と AIMS の得点}

との相関係数

\begin{tabular}{lccr}
\hline & 軟部腫瘍群 & 骨腫瘍群 & 切断群 \\
\hline pain & -0.115 & -0.153 & 0.046 \\
function & -0.158 & -0.292 & -0.302 \\
emotional acceptance & -0.133 & -0.039 & -0.648 \\
supports & $\dagger$ & $-0.445^{*}$ & -0.246 \\
walking ability & -0.401 & -0.253 & -0.226 \\
gait & -0.305 & -0.348 & -0.168 \\
total score & -0.216 & $-0.381^{*}$ & -0.274 \\
\hline
\end{tabular}

†：すべて 5 点であったため, 相関の測定は不可能. ${ }^{*}: p<0.05$ で相関あり。

得点の項目のみが, AIMS の得点と統計学的に有意な 相関を示していた（表 5).

\section{考 察}

今回の患肢温存手術を受けた軟部腫瘍例には骨切除 例が含まれていなかったため, 患肢温存例を骨腫瘍群 と軟部腫瘍群に分けて検討した.

軟部腫瘍群は, MSTS の 6 項目の得点が高く, AIMS の得点は低く，3群のなかでは機能予後は良好 で心理面の問題が少なく最も成績良好であった．特に MSTS の客観的下肢機能を示す〈supports〉〈walking ability〉〈gait〉の 3 項目の得点が高く, 補装具の使用 者がいなかったことからも，術後下肢機能は良好と考 えられた，その理由としては，軟部悪性腫瘍の広範切 除術では骨切除が行われなかったので，下肢の支持性 が損なわれることが少なく，かつ関節機能が温存され たことが考えられた。

一方, 骨腫瘍群の術後患肢機能は切断群と同等で あった。これは, 補装具の使用率が高かったことから, 骨切除による支持性の低下とその後の関節機能の低下 がその原因であると考えられた。骨腫瘍群のうち，内 補填材を用いて再建術が行われた症例に対しては，患 肢機能を長期にわたり維持するために，保護的な補装 具の使用が励行されていた.

次に, MSTS のなかで手術に対する受け入れ状況， すなわち満足度を示す〈emotional acceptance〉の項 目の得点は， 3 群間に統計学的な有意差は認められな かった. しかし, 骨腫瘍群で, MSTS の各項目の得点 と AIMS の得点との相関を調べると, 〈emotional acceptance〉の項目には相関は認められなかったが, 〈supports〉および合計得点との間には負の相関（ $\mathrm{p}<$ 0.05）が認められた。すなわち, MSTS の得点が低い 症例では AIMS の得点が高くなり, 不安や抑うつが多 い結果であったが, 満足度は低下していなかったこと より, 骨腫瘍群では術後患肢が機能不良であっても, 患肢温存術は患者に受け入れられているといえる.

Frieden $ら^{6)}$ も，小児の原発性下肢悪性骨腫瘍で人工 膝関節置換を受けた症例の分析を行い，患肢温存術は 患児だけでなく両親の満足度も高かったと述べ，また Postma ら ${ }^{7)}$ も, 患肢温存術は切断術よりも cosmetic advantage があり，患者に受け入れられていたと述べ ている.

今回の調查では AIMS による心理評価で 3 群間に 有意差は認められなかった。骨腫瘍群では手術に対す る満足度と AIMS との間にも相関はなかったが, 患肢 機能全体で比べると AIMS との間に負の相関が認め られた。これは, 日常生活に復帰すると, 骨腫瘍群は 自分自身の下肢を切断せずに残すことができてよかっ たと満足するが，温存された下肢機能が十分とはいえ ない場合は, 手術前と同様の活動や社会復帰が困難と なり,こんなはずではなかったと感じて心理的ストレ スが次第に蓄積するためではないかと考えられた。す なわち, 骨腫汮群では患肢温存術の受け入れは良好で あっても，実際の患肢機能に障害が多く残った場合に は心理面での問題が多かったといえる.

Sugarbaker ら ${ }^{8)}$ は, 術式の差が心理面に及ぼす影響 について, randomized controlled clinical trial によ る切断例と患肢温存例の比較検討を Psychological Adjustment to Illness Scale を用いて行ったが両者に 有意差が認められず，評価方法に特異性や鋭敏性が少 なかったためではないかと考察している。また, Weddington $ら^{9)}$, Harris $ら^{10)}$ は Beck Depression Inven- 
tory などを用いて切断例と患肢温存例の心理面の比 較検討を行ったが，同様に有意差が認められず，「患肢 温存術が心理面では切断術よりも有利である」という 仮説は証明されなかったと述べている

われわれの AIMS を用いた評価でも，3 群間で心理 面の差は認められなかったが，骨腫瘍群においては, 機能予後不良例は心理面も不良であった。 これは，従 来の報告は単に切断例と患肢温存例との間で比較検討 を行っており，それぞれの機能予後に注目して調査し ていなかったためと推察される。われわれは，機能予 後に注目して心理面を検討したことと，骨関節系の身 体障害が継続し，慢性の経過をたどるリウマチの評価 に用いられる AIMS のなかの心理面の項目を用いた ために,相関が検出されたのではないかと考えている.

また，今回の調査は原疾患の直接治療医ではないり ハビリテーション医によって行われたため，執刀医や 主治医に生じやすい思い入れが入らず，患者の評価は より客観的に行われ，しかも，患者の側からも遠慮せ ずに自由に発言しやすく，患者の本音を聴くことがで きたことも心理面の差が現れた原因の1つではないか と思われた。

切断群の機能予後は軟部腫瘍群より不良であった が, AIMSの得点は高くならなかった.これは, 切断 群では下肢がない現実があり，患者自身がこれを十分 に認識して，順応していこうとすることの表れかもし れない.

骨腫瘍例に対して患肢温存術が行われても，機能予 後が不良な場合は，特に心理面での配慮が必要である と考えられた。

(本論文の内容は, 第 31 回日本リハビリテーション医学会, 第 28 回日本整形外科学会骨・軟部腫瘍学術集会で報告し た）

\section{文 献}

1) Simon MA, Aschliman MA, Thomas N, Mankin $\mathrm{HJ}$ : Limb-salvage treatment versus amputation for osteosarcoma of the distal end of the femur J Bone Joint Surg 68-A : 1331-1337, 1986

2) Bacci G, Avella M, Mancini A, Leonessa C, et al : Primary chemotherapy and delayed surgery (neoadjuvant chemotherapy) for osteosarcoma of the extremities. Cancer 65:2539-2553, 1990.

3) Enneking WF, Dunham W, Gebhardt MC, Malawar $\mathrm{M}$, et al: A system for the functional evaluation of reconstructive procedures after surgical treatment of tumors of the musculoskeletal system Clin Orthop 286:241-246, 1993

4) Meenan RF, Gertman PM, Mason JH : Measuring health status in arthritis; the Arthritis Impact Measurement Scales Arth Rheum 23:146-152, 1980

5) Lerner RK, Esterhai JL Jr, Polomano RC, Cheatle MD, et al : Quality of life assessment of patients with posttraumatic fracture nonunion, chronic refractory osteomyelitis, and lower-extremity amputation. Clin Orthop 295:28-36, 1993

6) Frieden RA, Ryniker D, Kenan S, Lewis MM : Assessment of patient function after limb-sparing surgery Arch Phys Med Rehabil 74:38-43, 1993

7) Postma A, Kingma A, Ruiter JH, Koops HS, et al : Quality of life in bone tumor patients comparing limb salvage and amputation of the lower extrem ity J Surg Oncol 51: 47-51, 1992

8) Sugarbaker PH, Barofsky I, Rosenberg SA, Gianola FJ : Quality of life assessment of patients in extremity sarcoma clinical trials. Surgery $\mathbf{9 1}$ : 17-23, 1982

9) Weddington WW, Segraves KB, Simon MA : Psychological outcome of extremity sarcoma survivors undergoing amputation or limb salvage. J Clin Oncol 3:1393-1399, 1985.

10) Harris IE, Leff AR, Gitelis S, Simon MA : Function after amputation, arthrodesis, or arthroplasty for tumors about the knee. J Bone Joint Surg 72A : 1477-1485, 1990.

\title{
Postoperative Function and Psychological Problems in Patients with Malignant Musculoskeletal Tumors of the Lower Limbs
} by

\author{
Noriko MaRUno*1, Masahiro MIKami* \\ Shouzo Higaki ${ }^{* 2}$, Akio TAteishi ${ }^{* 2}$, \\ from
}

${ }^{* 1}$ Department of Rehabilitation Medicine, Teikyo University School of Medicine,

${ }^{* 2}$ Department of Orthopedic Surgery, ditto

(Jpn J Rehabil Med $33:$ 393-399, 1996) 
Postoperative function and psychological status were studied in 50 patients with musculoskeletal malignancies of the lower limbs. Postoperative functional evaluation of the operated limb was made using the Musculoskeletal Tumor Society scoring system (1993), and psychological evaluation was made using the Arthritis Impact Measurement Scale. The patients were divided into an amputation group and a limbsalvage group, and the latter was further divided into a bone tumor group and a soft tissue tumor group. No difference was observed in the degree of satisfaction about the operation or psychological condition among the three groups. However, in the bone tumor group, a poor functional outcome was associated with poor psychological status. 